KEMAS 13 (2) (2017) 158-168
Jurnal Kesehatan Masyarakat

\title{
INTERNAL STIGMA OF AN HIV-INFECTED HOUSEWIFE: A PHENOMENO- LOGICAL STUDY
}

\author{
Ossie Sosodoro ${ }^{1,2} \bowtie$, Riris Andono Ahmad ${ }^{3}$, Yayi Suryo Prabandari ${ }^{3}$, Mohammad Hakimi ${ }^{3}$ \\ ${ }^{1}$ Doctoral Program, Faculty of Medicine, Universitas Gadjah Mada, Yogyakarta, Indonesia \\ ${ }^{2}$ Ministry of Health of Republic of Indonesia, Jakarta, Indonesia \\ ${ }^{3}$ Faculty of Medicine, Universitas Gadjah Mada, Yogyakarta, Indonesia
}

\begin{tabular}{l} 
Article Info \\
\hline Article History: \\
Submitted Juni 2017 \\
Accepted Juni 2017 \\
Published November 2017 \\
\hline Keywords: \\
Stigma; housewife; \\
phenomenology \\
\hline DOI \\
http://dx.doi.org/10.15294/ \\
kemas.v13i2.9970
\end{tabular}

\begin{abstract}
In connection with the transmission of the HIV virus, housewives may have experienced internal stigma, which can have an effect on HIV prevention and the treatment of AIDS. Twenty-three HIV-infected housewives were interviewed in a qualitative study conducted in North Jakarta. The data were analyzed using a phenomenological approach. Seven themes emerged to explore internal stigma housewives and to compose the essence of the internal stigma. The essence of an HIV-infected housewife who has internalized the stigma can be illustrated as an Indonesian proverb which is "Hidup Segan Mati Tak Mau" or in English can be interpreted as 'having lost the will to live, but not wanting to die'. This could explain that AIDS forces them to live in anxiety in all aspects of life but as housewives, they must keep thinking about continuing life especially with regard to the future of their beloved children.
\end{abstract}

\section{Introduction}

AIDS is ranked fourth as the leading cause of death in adults worldwide (Azinar, 2016). The number of People Living with HIV/ AIDS (PLWHA) remained more or less stable at 3.5 million since 2005 and includes 1.3 million women aged 15 years and above. More than 99\% PLWHA live in 5 countries: India, Indonesia, Myanmar, Nepal, and Thailand (Pendse, 2016). The spread of HIV/AIDS in Indonesia has reached the stage of transmission which now involves housewives. The June 2016 HIV/AIDS development report of the Ministry of Health of the Republic of Indonesia conveyed that the status of housewife had the largest total number of HIV infections, up to June 2016, compared to the other statuses of
11,655 people. The Ministry of Health of the Republic of Indonesia also issued a Regulation by the Minister of Health No. 51 of 2013 on Prevention Guidelines for HIV transmission from mother to child, which requires pregnant women to have an HIV test. This regulation was also in response to the increasing number of cases of HIV transmission to housewives (Kementerian Kesehatan RI, 2016; Octavianty, 2015; Mahmudah, 2013).

There is another dimension of the stigma attached to HIV that receives less attention from researchers and program managers and is often referred to as internal stigma, which describes a feeling or the shadow of, or an actual perceived, stigma (Nugroho, 2017; Shaluhiyah, 2017). Internal stigma, or felt stigma, is the

\footnotetext{
Correspondence Address:

Doctoral Program, Faculty of Medicine, Universitas Gadjah Mada. Jl. Farmako Sekip

Utara Yogyakarta, Indonesia

Email : ossie_sosodoro@yahoo.com
} 
shame associated with HIV/AIDS, and the fear of being discriminated against because of the illness. Internal stigma affects the health care provider and the family who may also feel embarrassed, guilty or fearful. Internal stigma can affect the prevention of HIV treatment and the care for people living with HIV (USAID, 2006). Previous research has shown that the measurement of the internal stigma of PLWHA considers the social branches of the willingness of those people to have their status as PLWHA known, and their communities' reactions to AIDS (Kalichman, 2005). People with the stigma of PLWHA may feel more depressed and feel more miserable than those who have not internalized the stigma of PLWHA. According to research, internal stigma is affected by gender construction, homophobia, guilt and innocence construction, class and race (USAID, 2006; Phillips, 2011).

PLWHA women in Indonesia have different characteristics than other HIVpositive women in the world (Rahmalia, 2015). This study aimed to explore the life experience of HIV-infected housewives with internalized stigma to give an input into prevention programs and health care services.

\section{Methods}

This was a qualitative research using the phenomenology approach which is a research method that describes the essence of life experiences (Creswell, 2014). In this phenomenological research, we tried to describe the essence of life experiences as housewives with internalized stigma. The study used thematic analysis to identify the themes from transcripts according to the interviews with participants.

The research was conducted in North Jakarta, Indonesia. The background using Jakarta as the research site involves the greatest number of reported cases of HIV infection in Indonesia. As of June 2016, there were 31,586 cases of infection, which is the highest number of cases among all the provinces in Indonesia (Kementerian Kesehatan RI, 2016). The participants have visited Koja Hospital in North Jakarta to seek treatment and to participate in peer support group meetings. Selected participants whose residence is close by was in line with the aim of the researcher to have more ease in approaching them, especially when planning to visit their homes. Most participants were interviewed at home but for different reasons some were met in hospitals and elsewhere. Most of the reasons some participants did not want to be visited at home was because of work and they had feelings of being uncomfortable and vulnerable associated with the need for confidentiality of their status as PLWHA.

The twenty-three participants of this study were all HIV-infected housewives who did not work at the time of finding out about their HIV infection. The recruitment of participants was conducted by purposive sampling from data of PLWHA companions and the selection judgment was made by the researcher. The participants ranged in age from between 20 to 45 years old, and their levels of education varied considerably, from not going to elementary school up to the level of Education Diploma 1. None of the participants, when first learned of contracting HIV, worked, but by the time of the interviews with them, 14 still did not work, one was a motorcycle taxi driver, one worked in a cafe, and the rest worked either as laborers, traders or as assistants to PLWHA. Most of the participants are married, while the rest are widows, and 15 of them still have husbands who have a variety of jobs.

The data were collected from Indonesian-speaking participants by using a semi-structured questionnaire with in-depth interviews lasting for 45 to 60 minutes for each participant. Data collection started with the open questionnaire and all of the participant's statements were recorded by voice-recorder and typed as a verbatim transcript. Interview data were later typed in transcript form and read repeatedly by the researcher. The next level of questioning was to deepen their statements which were submitted so that the thoughts or feelings from the depths of their heart could be explored. In the implementation, almost all participants submitted this outpouring of heart to the researcher were often accompanied with glassy eyes or even with tears.

The interview ended when no new information was obtained from the participants. Before concluding the interview, the researcher confirmed the information that was considered 
unclear to the participants and the companion of PLWHA.

Interview data were recorded and typed in verbatim transcript form to be analyzed. Coding was done by looking for significant statements which were grouped into the subthemes according to similarity. Sub-themes were then grouped according to the general meaning of the theme. As a phenomenological study, the end result is developing the essence of the phenomenon experienced by the participant which is composed of existing themes (Creswell, 2014).

Previously the researchers have never known any PLWHA but only conducted research on PLWHAs from the outside point of view without the direct involvement with a PLWHA. Initially to recognize and approach participants, the researchers needed assistance from PLWHA companions who had previously been considered as part of the HIV-infected community.

For credibility, the researcher spent time in the field to get closer to the participants by coming to their homes and attending peer support group meetings. A PLWHA companion always accompanied them during the interview in order for the participants to feel more secure and comfortable with the researcher. The researcher read the transcript many times and also discussed it with the PLWHA companion for confirmation. The interview was conducted several times for each participant and terminated after there was no more new information from the participants. Triangulation of data was done by conducting a confirmation interview with a husband or relative who lives in the same house.

\section{Results and Discussion}

The themes were derived from the reduction of verbatim transcripts from in-depth interviews. After going through the search for important words which were then grouped into 19 sub-themes, the researcher compiled them into 7 themes. These seven themes were later developed into the essence of the phenomenon under study. These are illustrated in Figure 1.

The thought of death occurred to most of the participants. The thought of AIDS as a lethal disease which has no cure, haunted most of the participants, especially in the early days after contracting HIV. This perception disturbed their minds, making the participants feel like just accepting their deaths without doing anything. There were also participants who became stressed, which interfered with their lives because it became difficult for them to sleep and eat, and made them uncomfortable, because they were wondering if tomorrow they would still be alive or not, as shown in the following statement:

"Initially I thought it was a deadly
disease. When I knew my husband
was infected, I felt as if I was also
infected because we were already
married for 8 years ... I feel sincere
... ordinary ... everyone will
surely die. We took the option to
continue treatment and repent....
so we are better prepared to die"
(P.2, contracted from husband,
not working, 26 years old)

Feelings of fear occur because they assume that if people have been diagnosed with this disease, they would eventually die. They were afraid and eventually become stressed and depressed, because in addition to thinking about their condition, they also worried about the future of their family and their children, who were still young. They felt stressed out about their death, and for their children who were likely to have been infected as well. While undergoing treatment, they still think that death will come soon:

\section{"Once you know the results you are immediately torn, thrown away, stressed. Tomorrow I would die ... think about my children's future. Already chaotic, until the will to live is no more. The point already imagined was death tomorrow morning ... did not know how to find a cure." (P.22, contracted from husband, companion of PLWHA, 44 years old)}

This condition will get worse when coupled with thinking about the stigma and discrimination they will face from their communities. This is what one participant said: 
Figure 1. Seven Majors Theme were Constructed from 19 Sub-theme for Discovery the Essences of Phenomenon

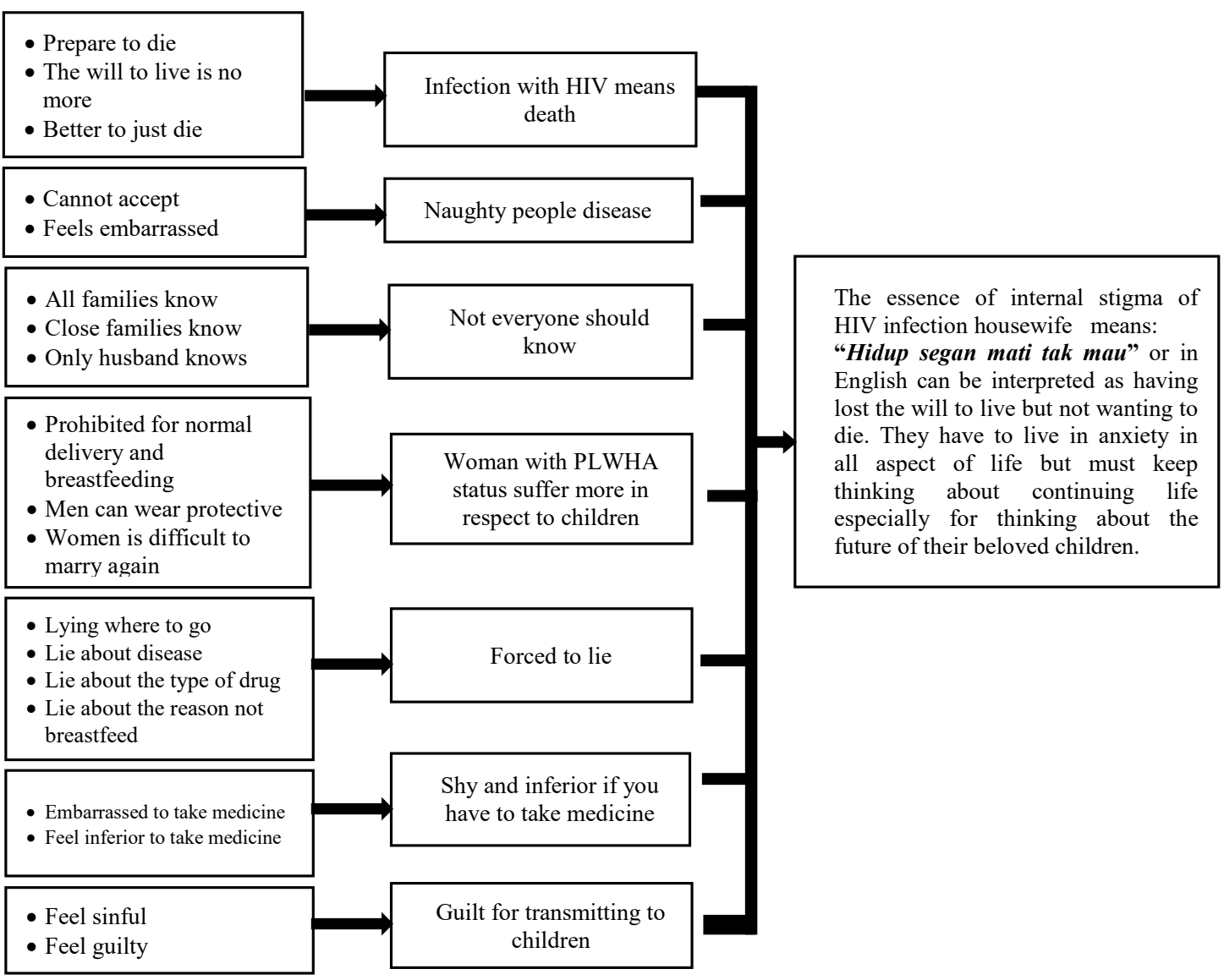

"Better to just die rather than bear the burden. Because HIV is very bad for the body. From the environment, let alone from outside, the family is not necessarily willing to accept. Because the HIV disease is deadly and has no cure." (P.11, contracted from husband, not working, 40 years old)

After discovering how contagious HIV is, the main picture in the minds of the participants is their death. Many researchers found this situation happening in their researches. This finding means that the perception of death by similar participants differs from that experienced by PLWHAs from around the world (Mo, 2014). Many PLWHAs always thought that contracting HIV means death, as was found by an American research team examining the thoughts of people living with HIV and AIDS, which illustrated that many felt that AIDS meant an inevitable death (Anderson, 2002). With modern treatment methods and supports, many PLWHAs are actually now living longer and leading productive, fulfilling lives. Another aspect of the personal testimonies discovered is that many PLWHA feel closer to God in their critical condition (Sukarja, 2017).

Several participants considered HIV as a "misbehavior" disease, caused by promiscuity, or free sex. This often makes it hard for the participants to accept their status as HIVinfected persons, such as demonstrated in the following participant's statement:

“Cannot accept because I'm not a naughty person. Everyday I'm crying constantly...cannot accept it, hoping it's just a dream." 
(P.3, HIV transmission source is unclear, not working, 25 years old)

A similar statement was made by a patient who was embarrassed to find herself living with HIV because her thoughts about HIV transmission would only apply to mischievous women. As she said:

"It feels embarrassing, I'm
afraid of being seen as a
naughty woman, whereas I
contracted it from my husband."
(P.17, HIV transmission source is
unclear, not working, 29 years old)

Some participants think AIDS is a disease for "naughty" people. They think that AIDS will only be experienced by people who have bad behavior, such as people who have sex with multiple partners (free sex) or are drug users. It is not surprising that the participants feel embarrassed and did not expect to be infected with HIV, as reflected in their thinking. This finding may be similar with experiences by PLWHAs in other countries. One study in South Africa also showed the same finding, which is the thought that AIDS is only a disease for a naughty person (Rule, 2008). In Ghana, the study described the HIV-infected women felt sad, shy and embarrassed because they had contracted a disease that society label as "bad" (Wright, 2010).

Having the status of a PLWHA is not an easy way in life for the participants, nor it is for their families. The average participant still thinks that their family will find it difficult to accept them, unlike before, because of their illness. They think that the family will look down on them because of their illness. It may also be that the participants were worried that their families will tell their neighbors about their disease. A participant's statement about her family knowing her status as a PLWHA is shown as follows:

"All the family knows ... father, mother, children, sister and uncle, brother-inlaw .... to the neighbors they say it was an accident, sick with pulmonary tuberculosis, because they fear that the son will become a social outcast. Because people's understanding of this disease is limited."

(P.2, contracted from husband,

not working, 26 years old)

Some participants did not want to disclose their status as a PLWHA to their whole family; only to some of the members did they want to be open. It also depended on the participants' perceptions of their families. Participants study their family members, to find those they consider able to keep their status as PLWHA private, or thought to be able to accept their status as PLWHA without discrimination. Statements concerning families who know the HIV-infected status include people close with the families, and they used the term "close family" to express them as shown in the following quotation:

"The close family already knows everything. Some of the husband's family know ... people around no one knows. We fear being expelled if others know. Because other people who were affected by HIV have also been expelled from that environment." (P.4, contracted from husband, not working, 39 years old)

The husband is the person who is closest to the participants, so it is not surprising that there are participants who only declared their status as PLWHA to their husbands. In this study, only two participants were willing to disclose their status as PLWHA to their husbands. Incidentally, in this study, the husbands were also infected or have tested HIV positive, as well as some of the children. Since only their husbands knew that the participants were PLWHA, this secrecy caused the interviews to be conducted in the homes of the participants, in a room with only the participant and her husband were present, while the other family members, such as parents and siblings, remained outside the room, and they did not know why the researcher was there. Regarding being open as a PLWHA to the husband alone, this can be shown in the following statement:

"Only my husband knows ... other family members do not know ... are not to be told ... I'm afraid of being ostracized, despised, avoided ... neighbors do not know. Because 
people's view of this disease is ugly. They will think about a malignant and contagious disease ... I'm afraid of being shunned by my neighbors." (P.8, contracted from husband, not working, 40 years old)

Due to their thinking, the participants generally do not want their status to be known by the wider community, or by their family and even by their own husbands. They fear that this will cause them to experience discrimination. They have also heard that PLWHA face a great deal of discrimination, so they decided to keep their status as AIDS sufferers a secret. This is also experienced by PLWHA around the world, who face the situation in which people are not friendly to people living with HIV, and just want to stay away from them; this shunning will encourage the resistance of PLHWHA to open their status as PLWHA and actually increases the internal stigma of PLWHA. A greater fear driving their unwillingness to let their status as PLWHA become known is their fear of being shunned. However, a willingness to let their status as PLWHA be known is a gateway to HIV prevention. A willingness to open their status as PLWHA is important for health promotion, social support, welfare, and disease prevention (Kingori, 2012; Tsai, 2013; Geary, 2014). Another study in Canada described that disclosing HIV status involves living the ambivalence of a paradoxical process of revealing/concealing, in a state of profound suffering, exacerbated by stigma, while is also being enriched by the benefits attained (Rouleau, 2012).

A participant who contracted HIV at the time of her child's birth complains that she had to experience something that is not really desirable: being forced to deliver her child by cesarean section, and after the child was born she was not allowed to breastfeed her child. Participants felt disappointed with this situation and the inability of the participants to breastfeed is even more burdensome, since they have to hide this condition because people will wonder why they are not able to give milk to their babies. This secrecy forced them to look for reasons when someone asks why they do not want to breastfeed their children. This led the participants to suggest that women will be more likely to suffer if they are infected with $\mathrm{HIV}$, as presented below:

\begin{abstract}
"More burdensome to the mother who is infected .... firstly because they know they have contracted the virus ... and are disappointed at not being allowed to give birth normally. Secondly, very heavy, sad hearts because they are not allowed to breastfeed their children." (P.3, method of contracting unclear, not working, 25 years old)
\end{abstract}

A similar opinion was also conveyed by a participant who said that it was easier for a woman infected with HIV to it transmit to her children, either in the womb or at birth or through breast milk. If a man is infected but uses a condom, he will normally be able to prevent transmission of the virus. It is different if the mother-to-be is infected because it can easily be transmitted to her child, as in the following participant's statement:

\begin{abstract}
"Heavier burden for a woman, because it could easily infect her son. Men can wear protection, but women cannot." (P.19, contracted from husband, not working, 37 years old)
\end{abstract}

The other participants were more concerned with a mother's responsibility to the child in relation to his/her development. Mothers are considered to be much more concerned about their children than the husbands are, because the husbands will usually get married again, while women would think first about the development of their children before marrying again. This appears in the participant's statements as follows:

"Heavier burden for a woman, if she has children. Her husband can marry again if she dies. But a wife cannot ... pity the children if she married again and her new husband is not necessarily willing to accept them." (P.7, contracted from husband, not working, 22 years old)

The participants thought that women who contracted HIV experienced greater 
suffering than men. This finding is related to their responsibilities as mothers, who feel more responsible for taking care of the children than their husbands. Not much difference, a study in Batswana also illustrated the mother's concern for the child's future with respect to her illness (Molefe, 2009). This sentiment is quite interesting because it differs from a study in Ghana which conveyed that women living with HIV / AIDS experience more severity when contracting HIV because in general, while also disregarding the welfare of the children, the husbands will continue to expect to be served by their wives (Vigneshwaran, 2013).

Due to the unwillingness of participants to disclose their status as PLWHA, the participants were forced to lie to cover the fact that they had to go to visit a hospital or clinic in relation to the HIV infection they suffered. One participant submitted a statement saying she had to lie every time she had to go to the hospital; she would say she would go to her sister's place, as disclosed in her statement:

\section{"My neighbor is less aware of the disease. If you want to stay in control, say you are going to your brother's house, do not say to the hospital." (P.21, contracted from husband, not working, 35 years old)}

Often the participants also must answer questions addressed to them about their illness, and why they had to go for treatment so often. A participant who once worked stated that she would lie to her boss and his friends by mentioning she suffered from lung disease in order to be able to still have work. This tendency to lie about the disease is shown as follows:

\footnotetext{
"Tell the boss and friends you have lung disease, in order to be able to keep working and not be avoided." (P.19, contracted from husband, not working, 37 years old)
}

Another aspect that made the participants uncomfortable was that they must take medication regularly and continuously. Not infrequently participants were asked questions about what the drugs/medicine were for that they were seen taking every day. Participants generally have to lie to answer that question out of fear of their status being exposed. Some participants gave the answer "drink vitamins" to anybody asking them. This is stated by the following participant:

\section{"My third husband once asked about the drugs I was taking, but I answered it is only a vitamin." (P.20, HIV infected due to risky behavior, not working, 32 years old)}

One participant who was forced not to breastfeed her child, because of contracting $\mathrm{HIV}$, is often also asked by people around her why she does not want to breastfeed. She was forced to lie and say that her milk was not coming out. This is what the participant said:

$$
\begin{aligned}
& \text { "Neighbors do not know, I'm afraid if } \\
& \text { they know I'll be avoided. The neighbor } \\
& \text { asked why I do not breastfeed my son, } \\
& \text { I answered my milk did not come out." } \\
& \text { (P.7, contracted from husband, } \\
& \text { not working, } 22 \text { years old) }
\end{aligned}
$$

As people who are infected with HIV, they can receive treatment for their condition. But to get that the participants must go to their health service provider to check their progress or to get their medicine. The participants felt that this is quite a hassle because they must answer questions from different people about why they were going to the hospital, why they were taking medicine and what kind of illness they had. A thesis research from Africa shows that those infected would often lie about their illness (Kim, 2003).

Due to the embarrassment, they feel there were participants who did not want to come for treatment on a regular basis. According to the researcher's observations at a peer-to-peer meeting, the participants were also absent. Their companions are still trying to convince the participants to come for treatment. However, the participants only encouraged their children to seek treatment, while they did not want to take the medicine. This reticence is shown in the following statement:

"Until now I've not been treated, because of shame. How can I come 
to this, like go ... trade problems, nobody delivers and they keep their merchandise ... could take the medicine but I stopped because I kept feeling nauseous." (P.5, contracted from husband, trader, 37 years old)

Participants also conveyed their feelings of being inferior with regards to the treatment they received as a PLWHA, they felt different from the other patients who came with different diseases, because the drugs they had to take had to be taken continuously and in a timely manner. Also, they are certain that although they are taking medicine, their illness will not be cured. This situation causes the participants to feel inferior and feel different from normal people who are seeking treatment. This sentiment is revealed by the following statement:
"See, if the people are sick with a cough, cold, or a headache they will not take their medicine for a month or longer because they can stop when they feel better. That's the difference, I feel inferior." (P.4, contracted from husband, not working, 39 years old)

In gaining access to health services the participants often experienced some uncomfortable situations and felt inferior, because they had to continue to seek treatment. This happened because when they went for treatment, the participants always get questioned about why they were going to the hospital or clinic, and eventually they thought it would be better if they had not seek treatment. The participants must answer questions every time they went for treatment, and this burdened them as they often had to lie to answer them. In a United States study, a 16-year-old boy was told that he had to lie so that he wouldn't lose a friendship (De Carvalho, 2006). This is probably one of the reasons why PLWHA feel that they should lie about their disease.

Participants also felt ashamed of having to receive treatment as a patient with HIV / AIDS. Participants also felt they were treated differently, so they often felt embarrassed when receiving treatment. In Nepal, a study of
82 participants found that $30.5 \%$ of them felt embarrassed having to take AIDS related virus (ARV) medications (Karki, 2016). Shame and depression have a close relationship. According to a recent research, internal stigma will indirectly affect the emergence of depression, mediated by the presence of shame (Li, 2009). This research was also reinforced by findings indicating that depressive disorders are directly related to an unwillingness to seek treatment (Olisah, 2010).

The participants had feelings of guilt in relation to their HIV-infected children since innocent children were infected with HIV from their mother. This is in accordance with the participant's statement as follows:

\begin{abstract}
"Sad, because my child got infected and now has to take medication for life ... my son is not wrong, my husband is the one who is wrong, but we have to accept the impact. That's what irritates me. I feel sinful because of my child. He does not understand ... if he knew since born he would be rejected ... what I always regret is when he is taking his medicine he always asks what is this for mama?" (P.4, contracted from husband, not working, 39 years old)
\end{abstract}

Participants expressed their guilt for their infected child's condition, thinking that their child should take a fixed schedule of medication daily, and the hardest part is it needs to be taken for the rest of their lives. This is what makes the participants become saddened because it means that their children cannot live normally like other children. The participants also think about the future of their children, when they grow up. An example of the participants' thinking is as follows:

"Feeling guilty ... just think this way, I want to try to fight because I have a child ... this is my fault that he is positive ... anyway, he should live, he must have a future. I don't want to keep him isolated. I want him to be successful and rewarded." (P.20, contracted due to risky behavior, not working, 32 years old) All of the participants felt guilty about 
passing HIV to their children. They felt that the child's infection was because of their infection. They felt sad because they had to see their children, who should be like other children but are now infected by HIV and therefore must lead a different life. The guilty feelings of mothers transmitting HIV were clearly recorded in our study. The results were very similar to those experienced by women of Mexican descent living with HIV in the United States, who were participants in a research dissertation, and who expressed guilt over the HIV infections experienced by their children. Furthermore, a study in Cameroon submitted that this guilt will cause people to not want to marry again, to not want to have sex and to not want to have more children (Jacobi, 2013).

The seven themes of the study contributed to the emergence of the essence of internal stigma. Illustrating the essence of an HIV-infected housewife who has internalized the stigma is like an Indonesian proverb that says "Hidup Segan Mati Tak Mau" or in English can be interpreted as "Having lost the will to live, but not wanting to die'. This can be explained by the fact that the disease forced them to live in anxiety in all aspects of life but they had to keep thinking about continuing life especially because they were thinking about the future of their beloved children. Participants expressed the feelings of fear of: being close to the death; being exposed of having the status as PLWHA, being discriminated, and being labeled as bad person while still having to think about the future of their children.

Everyone is afraid of death. But the participants felt that their death was coming soon. This thought may be causing the participants to become depressed that sleeping and eating became uncomfortable. This situation illustrated the participants' anxiety regarding death.

During the interviews the secrecy of the status as an HIV-infected person emerged. As long as the internal stigma is still attached to the participants, the life of these participants will be in fear of their status becoming openly known. This condition may give rise to the anxiety of internal stigma which begins from the first time that they learnt about having contracted HIV until the end of their lives.
Discrimination experienced or heard by PLWHA can cause uncomfortable, upset, and depressed feelings. The anxiety also arose from being worried about this situation. Fear of discrimination will cause PLWHA to choose to distance themselves from the community. This reaction was very influential on the willingness of participants to access health services as PLWHA.

Participants feared to be labeled as a bad person from the first time they knew about contracting HIV. They still think of AIDS as a disease for a particular group of naughty people and as a misbehavior disease. This false impression may lead to embarrassment or inferiority and ultimately lead them to become isolated from the community, and also may reinforce an unwillingness to socialize or not to come to a healthcare provider for proper treatment.

For the participants, as HIV-infected mothers, their children were a priority in every thought and action taken. This deep felt sentiment was revealed in all of the research themes and never was lost in their minds especially when relating to the future of their children.

The aim of this qualitative study was to explore the internal stigma of housewives who were HIV-infected. The seven theme were developed to reflect the essence of the internal stigma as "Hidup Segan Mati Tak Mau". The anxiety manifestation which affects all of their lives includes accessing health services while they still have to keep thinking about their children. This study aimed to improve the understanding of the internal stigma that could hamper AIDS prevention programs. The understanding of internal stigma should occur at all levels of society, especially the closest people and health care providers.

This study has various limitations. To explore the internal stigma, further research should be conducted with newly infected PLWHA, but in reality, it is very difficult to get them to want to become a participant. Concerning social welfare benefits, all participants have received assistance from NGOs (non-governmental organizations) for some time after knowing they were infected with HIV. This arrangement for support 
may have contributed to their willingness to participate in this study.

\section{Conclusion}

Internal stigma is still being experienced by the participants which can be described by an Indonesian proverb "Hidup Segan Mati Tak Mau". It is an anxiety manifestation of the participants, which affects all of their life activities including accessing health services, while they still have to continue to live because they were always thinking about the future of their children. The understanding of internal stigma should occur at all levels of society, especially the closest people and health care providers.

\section{Acknowledgements}

The authors would like to thank LSM Lentera Anak Pelangi Unika Atmajaya Jakarta and the participants and the research assistants for their help in completing this research.

\section{References}

Anderson, E.H. \& Spencer, M.H. 2002. Cognitive Representations of AIDS: a Phenomenological Study. Qualitative Health Research, 12(10) : 1338-1352.

Azinar Mohammad, M.A.B. 2016. The Sexual Behavior of Male Sexual Partner of Tranvestite in the Prevention Efforts of HIV/AIDS transmission. Jurnal Kesehatan Masyarakat, 12(1) : 25-33.

De Carvalho Mesquita Ayres, J.R. et al. 2006. Vulnerability Human Rights, and Comprehensive Health Care Needs of Young People Living with HIV/AIDS. American Journal of Public Health, 96(6) : 1001-1006.

Creswell, J.W., 2014. Penelitian Kualitatif dan Desain Riset, Memilih diantara Lima Pendekatan,edisi 3 diterjemahkan dari Qualitative Innquiry \& Reaserchh Design: Choosing Among Five Aproaches Third edit.,

Geary, C. et al., 2014. Gender Differences in HIV Disclosure, Stigma, and Perceptions of Health. AIDS Care, 26(11) : 1419-1425.

Jacobi, C.A. et al., 2013. HIV / AIDS-related Stigma Felt by People Living with HIV from Buea, Cameroon. AIDS Care, 25(2) : 173-181.

Kalichman, S.C. et al., 2005. Development of a Brief Scale to Measure AIDS-related Stigma in South Africa. AIDS and Behavior, 9(2) : 135-143.

Karki, J. \& Shakya, S. 2016. Problems Faced by Antiretroviral ( ARV ) Drug Users in Kathmandu. J Nepal Health Research Council, 14(1) : 27-32.
Kementerian Kesehatan RI, D.P. 2016. Laporan Situasi Perkembangan HIV-AIDS \& PMS di Indonesia April-Juni 2016, Jakarta.

Kim Hall, S., 2003. Phenomenological Investigation into the Lives of HIV Positive South African. (Thesis) University of Zululand.

Kingori, C. et al., 2012. Impact of Internalized Stigma on HIV Prevention Behaviors Among HIVInfected Individuals Seeking HIV Care in Kenya. AIDS Patient Care and STDs, 26(12) : 761-767.

Li, L. et al. 2009. Stigma, Social Support, and Depression among People Living with HIV in Thailand. AIDS Care, 21(8) : 1007-1013.

Mahmudah, U., Cahyati, W.H. \& Wahyuningsih, A.S. 2013. Pemanfaatan Voluntary Counseling and Testing oleh Ibu Rumah Tangga Terinfeksi Human Immunodeficiensy Virus. Jurnal Kesehatan Masyarakat, 8(2) : 113-120.

Mo, P.K.H. et al. 2014. A Model of Associative Stigma on Depression and Anxiety Among Children of HIV-Infected Parents in China. AIDS and Behavior : 50-59.

Molefe, T. \& Duma, S. 2009. Experiences of Batswana Women Diagnosed with Both HIV / AIDS and Cervical Cancer. Ogy Nursing Forum, 24(5) : 29-32.

Nugroho, Efa. et.al. 2017. Counseling Model Development Based on Analysis of Unwanted Pregnancy Case in Teenagers. Jurnal KEMAS, 13(1) : 137-144

Octavianty Lenni; Rahayu Atikah, R.D. 2015. Pengetahuan, Sikap dan Pencegahan HIV / AIDS pada Ibu Rumah Tangga. Jurnal Kesehatan Masyarakat, 11(1) : 53-58.

Olisah, V.O., Baiyewu, O. \& Sheikh, T.L. 2010. Adherence to Highly Active Antiretroviral Therapy in Depressed Patients with HIV / AIDS Attendinga Nigerian University. African Journal of Psychiatry : 275-279.

Pendse, R. et al. 2016. HIV / AIDS in the SouthEast Asia Region: Progress and Challenges. Journal of Virus Eradication, 2 (Supplement 4) : 1-6.

Phillips, K.D. et al. 2011. Social Context of Rural Women with HIV/AIDS. Issues in Mental Health Nursing, 32(6) : 374-381.

Rahmalia, A. et al. 2015. Women with HIV in Indonesia: are they Bridging a Concentrated Epidemic to the Wider Community $B M C$ Research Notes, 8(1) : 1-8.

Rouleau, G., Côté, J. \& Cara, C. 2012. Disclosure Experience in a Convenience Sample of Quebec-born Women Living with HIV: a Phenomenological Study. BMC Women's Health, 12(1) : 37 . 
Rule, P. \& John, V. 2008. Unbinding the Other in the Context of HIV / AIDS and Education. Journal of Education, $43: 88$.

Shaluhiyah, Zahroh. Suryoputro, Antono. \& Setyawati, Any. 2017. The Needs of Information Services on Reproductive Health, STIs and HIV in Middle Adolescence. Jurnal KEMAS, 12 (2) : 233-242

Sukarja, I.M. et al. 2017. Experiences of People with HIV / AIDS ( PLWHA ) at the Critical Condition due to AIDS. International Journal of Research in Medical Sciences, 5(4) : 13571362.

Tsai, A.C. et al. 2013. Internalized Stigma, Social Distance, and Disclosure of HIV Seropositivity in Rural Uganda. Annals of
Behavioral Medicine, 46(3) : 285-294.

USAID. 2006. A Closer look: The Internalization of Stigma Related to HIV, Policy Project c/o Futures Group One Thomas Circle NW. Suite 200, Washington DC.

Vigneshwaran, E. et al. 2013. Gender Differences in Health Related Quality of Life of People Living with HIV/AIDS in the Era of Highly Active Antiretroviral Therapy. North American Journal of Medical Sciences, 5(2) : 102-107.

Wright, S.C.D. \& Mwinituo, P.P. 2010. Lived Experiences of Ghanaian Women Diagnosed with HIV and AIDS. Africa Journal of Nursing and Midwifery, 12(2) : 36-47. 